7. Stentoft J, Hokland P, Ostergaard M, Hasle H, Nyvold CG. Minimal residual core binding factor AMLs by real time quantitative PCR - initial response to chemotherapy predicts event free survival and close monitoring of peripheral blood unravels the kinetics of relapse. Leuk Res. 2006;30:389-95.

8. Weisser M, Haferlach C, Hiddemann W, Schnittger S. The quality of molecular response to chemotherapy is predictive for the outcome of AML1-ETO-positive AML and is independent of pretreatment risk factors. Leukemia. 2007;21:1177-82.

9. Lane S, Saal R, Mollee P, Jones M, Grigg A, Taylor K, et al. A or $=1$ log rise in RQ-PCR transcript levels defines molecular relapse in core binding factor acute myeloid leukemia and predicts subsequent morphologic relapse. Leuk Lymphoma. 2008;49:517-23.

10. Narimatsu $H$, Iino $M$, Ichihashi $T$, Yokozawa $T$, Hayakawa $M$, Kiyoi $\mathrm{H}$, et al. Clinical significance of minimal residual disease in patients with $\mathrm{t}(8 ; 21)$ acute myeloid leukemia in Japan. Int $\mathbf{J}$ Hematol. 2008;88:154-8.

11. Yin JA, O'Brien MA, Hills RK, Daly SB, Wheatley K, Burnett AK. Minimal residual disease monitoring by quantitative RT-PCR in core binding factor AML allows risk stratification and predicts relapse: results of the United Kingdom MRC AML-15 trial. Blood. 2012;120:2826-35.

12. Zhu HH, Zhang XH, Qin YZ, Liu DH, Jiang $H$, Chen $H$, et al MRD-directed risk stratification treatment may improve outcomes of $t(8 ; 21)$ AML in the first complete remission: results from the AML05 multicenter trial. Blood. 2013;121:4056-62.

13. Krauter J, Gorlich K, Ottmann O, Lubbert M, Dohner H, Heit W, et al. Prognostic value of minimal residual disease quantification by real-time reverse transcriptase polymerase chain reaction in patients with core binding factor leukemias. J Clin Oncol. 2003;21:4413-22.

14. Ragon BK, Daver N, Garcia-Manero G, Ravandi F, Cortes J, Kadia T, et al. Minimal residual disease eradication with epigenetic therapy in core binding factor acute myeloid leukemia. Am J Hematol. 2017;92:845-50.

15. Marcucci G, Mrozek K, Ruppert AS, Maharry K, Kolitz JE, Moore JO, et al. Prognostic factors and outcome of core binding factor acute myeloid leukemia patients with $t(8 ; 21)$ differ from those of patients with inv(16): a cancer and leukemia group B study. J Clin Oncol. 2005;23:5705-17.

\title{
Residual normal B-cell profiles in monoclonal B-cell lymphocytosis versus chronic lymphocytic leukemia
}

\author{
Ignacio Criado ${ }^{1}$ - Elena Blanco ${ }^{1}$ - Arancha Rodríguez-Caballero ${ }^{1} \cdot$ Miguel Alcoceba $\mathbb{1}^{2} \cdot$ Teresa Contreras $^{3}$. \\ María Laura Gutiérrez ${ }^{1}$ - Alfonso Romero ${ }^{4}$ - Paulino Fernández-Navarro ${ }^{5}$ - Marcos González ${ }^{2}$ - Fernando Solano ${ }^{6}$. \\ Carlos Gómez ${ }^{6}$. Martín Pérez-Andrés ${ }^{1} \cdot$ Jacques J. M. van Dongen ${ }^{7}$ - Julia Almeida ${ }^{1}$. \\ Alberto Orfao ${ }^{1}$. EuroFlow PID Group and The Primary Health Care Group of Salamanca for the Study of MBL
}

Received: 24 January 2018 / Revised: 27 April 2018 / Accepted: 1 May 2018 / Published online: 21 June 2018

(c) The Author(s) 2018. This article is published with open access

Chronic lymphocytic leukemia (CLL) is the most common adult leukemia in Western countries, which is characterized

These authors contributed equally: Julia Almeida, Alberto Orfao.

Electronic supplementary material The online version of this article (https://doi.org/10.1038/s41375-018-0164-3) contains supplementary material, which is available to authorized users.

Alberto Orfao

orfao@usal.es

1 Cancer Research Center (IBMCC, USAL-CSIC), Department of Medicine and Cytometry Service (NUCLEUS), University of Salamanca, CIBERONC and IBSAL, Salamanca, Spain

2 Hematology Service, University Hospital of Salamanca, IBMCC, CIBERONC, IBSAL and Department of Nursery and Physiotherapy, University of Salamanca, Salamanca, Spain

3 Biochemistry Service, University Hospital of Salamanca, by the accumulation of mature $\mathrm{CD} 5^{+} / \mathrm{CD} 20^{\mathrm{lo}} / \mathrm{CD} 23^{+}$clonal B-cells in peripheral blood (PB), bone marrow (BM), and other lymphoid tissues [1]. Currently, it is well-established that CLL is systematically preceded by a pre-leukemic stage, known as monoclonal B-cell lymphocytosis (MBL) [2]; MBL includes both low-count $\left(\mathrm{MBL}^{\mathrm{lo}}\right)$ and high-count MBL (MBL ${ }^{\mathrm{hi}}$ ), depending on the number of PB clonal Bcells $\left(<0.5 \times 10^{9} / \mathrm{L}\right.$ and $\geq 0.5 \times 10^{9} / \mathrm{L}$, respectively) detected

Salamanca, Spain

4 Centro de Atención Primaria de Salud Miguel Armijo, Salamanca, Sanidad de Castilla y León (SACYL), Castilla y León, Spain

5 Centro de Atención Primaria de Salud de Ledesma, Salamanca, Sanidad de Castilla y León (SACYL), Castilla y León, Spain

6 Hematology Service, Hospital Nuestra Señora del Prado, Talavera de la Reina, Toledo, Spain

7 Department of Immunohematology and Blood Transfusion, Leiden University Medical Center, Leiden, The Netherlands 


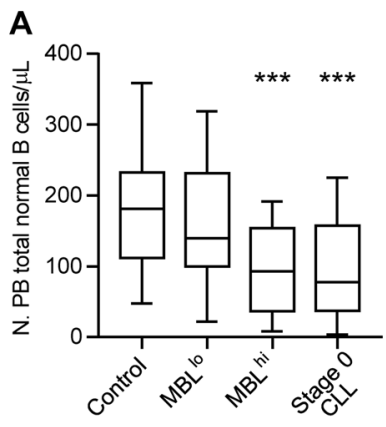

\section{B}

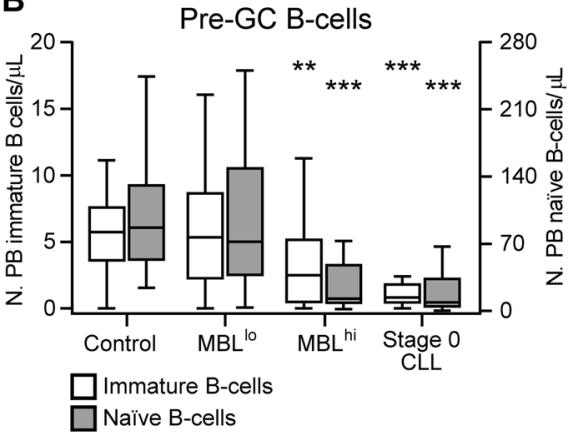

C

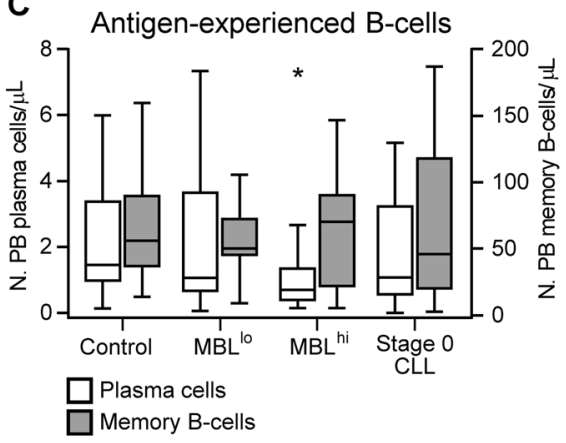

Fig. 1 Distribution of normal residual B-cells and their major subsets in peripheral blood of MBL and CLL cases vs. non-MBL controls. a The absolute number of residual normal B-cells. b The absolute number of pre-germinal center B-cells; white boxes represent immature B-cells (left $Y$-axis scale), while gray boxes represent naïve Bcells (right $Y$-axis scale). c The absolute number of antigenexperienced B-cells; white boxes represent plasma cells (left $Y$-axis scale), while gray boxes represent memory B-cells (right $Y$-axis scale).

[3], the former being a highly prevalent condition in adults $(\approx 25 \%$ of individuals $>70 y)[4,5]$. The biological and clinical significance of CLL-like clonal B-cells in PB of otherwise healthy individuals $\left(\mathrm{MBL}^{\mathrm{lo}}\right)$ has not been fully elucidated [6-8]. Recently, we have reported a very low rate of transformation of $\mathrm{MBL}^{\text {lo }}$ to $\mathrm{MBL}^{\text {hi }} / \mathrm{CLL}$, after 7 years of follow-up [8]. In contrast, we found a higher frequency of deaths in $\mathrm{MBL}^{\text {lo }}$ subjects vs. age- and sex-matched nonMBL healthy adults from the same geographical area; among the former subjects, infection was an overrepresented cause of death ( $21 \%$ vs. $2 \%$, respectively) [8]. This is in line with previous studies showing an $\approx 3$-fold increased risk of infection in both $\mathrm{MBL}^{\text {hi }}$ and CLL patients, in whom infections also represent a major cause of death $[9$, 10].

Altogether, the above findings suggest an impaired immune system and immune surveillance, already at very early CLL stages. So far, several immunological defects of both the innate and adaptive compartments of the immune system have been reported in CLL, including hypogammaglobulinemia and an impaired $\mathrm{T}$ - and NK-cell function [10]. However, the precise mechanisms that lead to this CLL-associated secondary immunodeficiency state still remain poorly understood, and little is known about the specific (pre-leukemic) stage of onset of the impaired immune response. Since hypogammaglobulinemia is one of the most common and relevant alterations involved in the secondary immunodeficiency of most CLL patients, here we investigated the composition of the residual normal PB Bcell compartment in both $\mathrm{MBL}^{\mathrm{lo}}$ and $\mathrm{MBL}^{\text {hi }}$ vs. early (Rai stage 0) CLL, to gain insight into the mechanisms involved in hypogammaglobulinemia in CLL, and the precise stage at which the first alterations occur.
In all panels, notched boxes represent 25 th and 75 th percentile values; the lines in the middle correspond to median values and vertical lines represent the highest and lowest values that are neither outliers nor extreme values. $* P \leq 0.05$ vs. controls; $* * P \leq 0.01$ vs. controls; $* * * P \leq$ 0.001 vs. controls. $\mathrm{MBL}^{\text {lo }}$ low-count monoclonal B-cell lymphocytosis, MBL hi high-count monoclonal B-cell lymphocytosis, CLL chronic lymphocytic leukemia

Overall, 110 subjects-61 males (55\%) and 49 females (45\%); mean age: $72 \pm 11 \mathrm{y}$-were prospectively enrolled in this study between January 2015 and June 2017, with no seasonal differences in recruitment for the distinct groups analyzed. Subjects were classified into: controls (40 non$\mathrm{MBL}^{\text {lo }}$ healthy adults), $\mathrm{MBL}^{\mathrm{lo}}(n=27), \mathrm{MBL}^{\text {hi }}(n=21)$, and CLL stage 0 (CLL-0) patients $(n=22)$. Identification and characterization of residual normal PB B-cells and quantitation of immunoglobulin (Ig) levels was performed using high-sensitivity flow cytometry and nephelometry/ turbidimetry, respectively. Inclusion criteria, flow cytometry protocols, panels and reagents, as well as the immunophenotypic criteria used for the identification of the different PB B-cell subsets, together with the clinical and biological characteristics of all individuals analyzed, are detailed in Supplementary Methods, Supplementary Tables 1-4, and Supplementary Figure 1.

Overall, both MBL ${ }^{\text {hi }}$ and CLL-0 patients showed significantly reduced normal PB B-cell counts (Fig. 1a), at the expense of pre-germinal center (GC) (immature and naïve) B-cells $(P \leq 0.001$; Fig. 1b), while no significant differences were observed in MBL and CLL-0 vs. non-MBL controls regarding total $\mathrm{PB}$ memory $\mathrm{B}$ cells (MBC) (Fig. 1c). In turn, the overall PB plasma cell (PC) compartment was significantly reduced (vs. controls) among $\mathrm{MBL}^{\text {hi }}$ subjects $(P$ $=0.002$ ), but not in CLL and MBL ${ }^{\text {lo }}$ cases (Fig. 1c). These results confirm and extend on previous findings from our group showing that production and release of both immature and naïve $\mathrm{B}$-cells into $\mathrm{PB}$ is already reduced in MBL [11]. Currently, it is well-established that during adulthood, PB MBC and PC counts (but neither PB immature nor naïve B-cell numbers) progressively decrease with age [12]; therefore, age alone could not explain the lower pre-GC Bcell counts reported here among MBL ${ }^{\text {hi }}$ and CLL- 0 cases, 
Fig. 2 Distribution of PB antigen-experienced B-cell subsets expressing distinct Igsubclasses and soluble Igsubclass plasma titers grouped according to the position they occupy in the $I G H C$ gene blocks. a, b The absolute number of $\operatorname{IgM}^{+}$and switched plasma cells, respectively. c, $\mathbf{d}$ The absolute number of $\operatorname{IgMD}^{+}$ un-switched memory B-cells and switched memory B-cells are displayed, respectively. $\mathbf{e}, \mathbf{f}$ Soluble IgM titers in plasma and the sum of the soluble levels of the different switched Igsubclasses according to the distinct position that they occupy in the IGHC gene, respectively. b, c, and $\mathbf{f}$ White boxes represent the sum of those Ig-subclasses encoded in the second $I G H C$ gene block, while gray boxes represent the sum of those Ig-subclasses encoded in the third IGHC gene block. The relative position and order of the different gene segments of the $I G H C$ gene that encode for the different Ig-subclasses are depicted on the top of the figure. Notched boxes represent 25th and 75th percentile values; the lines in the middle correspond to median values and vertical lines represent the highest and lowest values that are neither outliers nor extreme values; $* P \leq 0.05$ vs. controls; $* * P \leq 0.01$ vs. controls; $* * * P \leq 0.001$ vs. controls. MBL ${ }^{\text {lo }}$ low-count monoclonal B-cell lymphocytosis, MBL ${ }^{\text {hi }}$ highcount monoclonal B-cell lymphocytosis, CLL chronic lymphocytic leukemia

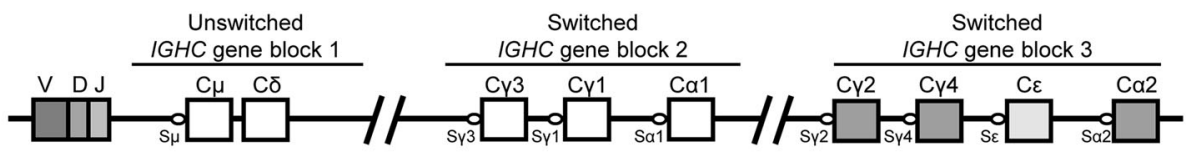

\section{A}

Total lgM $M^{+}$
plasma cells/ $/ \mu$

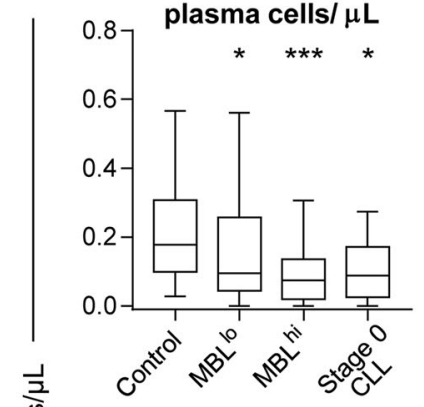

C Total un-switched memory B-cells/ $\mu \mathrm{L}$

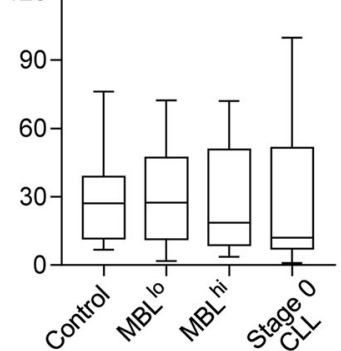

E Total soluble IgM (mg/dL)

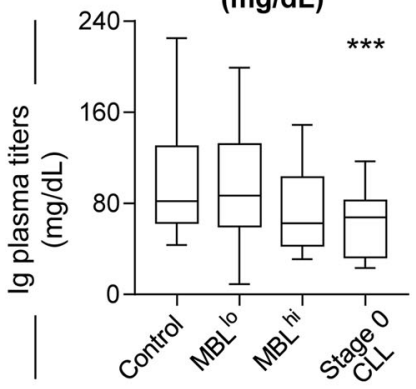

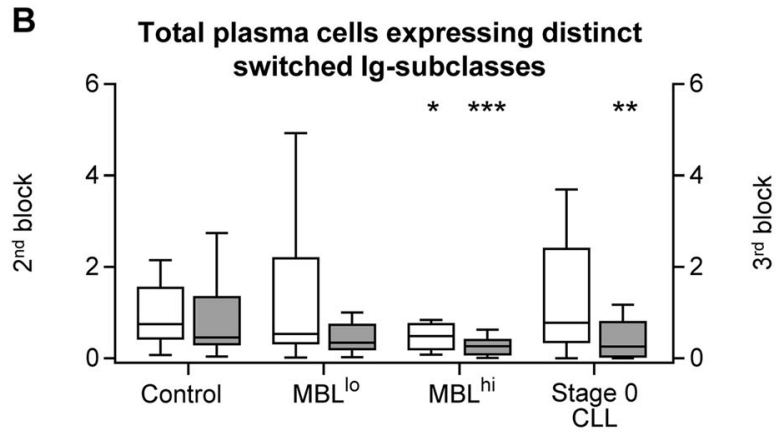

D

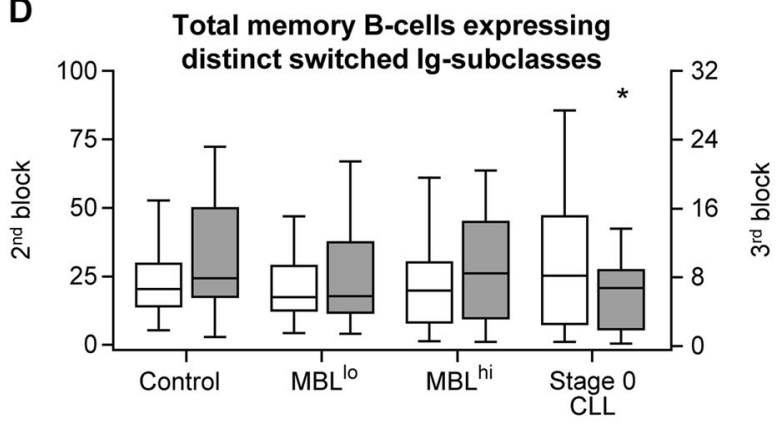

F

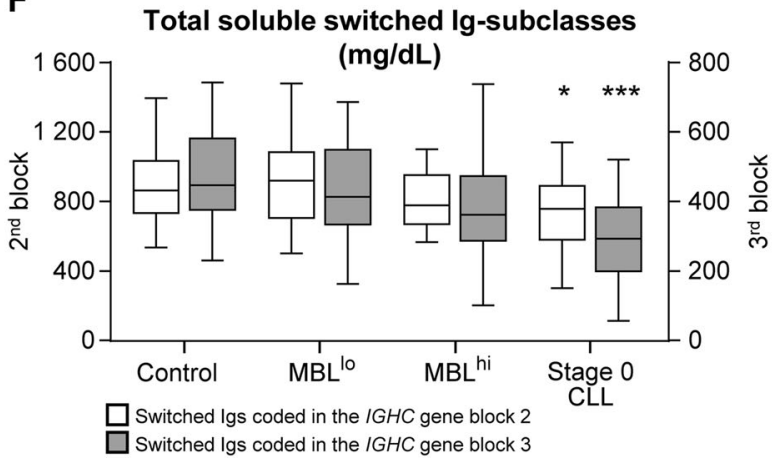

also because a similar age distribution was observed among all groups analyzed (Supplementary Table 4; Supplementary Figure 2). Conversely, the decreased numbers of preGC B-cells in PB of MBL ${ }^{\text {hi }}$ subjects suggests an impaired production of (newly generated) B-cells in the BM, already at the earliest disease stages. This might be due to a decreased number of available BM niches, as soon as they are (progressively) occupied by $\mathrm{CD}^{+}$CLL-like clonal Bcells. Thus, previous studies have suggested that BM infiltration by CLL cells displaces other resident cell populations (e.g., normal B-cell precursors), and generates an impaired hematopoietic microenvironment [13]. Interestingly, BM infiltration at early disease stages might preferentially affect the B-cell niches, since (by definition) no other cytopenias were observed in MBL and CLL-0 patients. BM analyses would then become crucial to better understand the underlying B-cell depletion mechanisms in these subjects; due to ethical reasons and the lack of medical indication for BM sampling in MBL, BM samples were not collected here. However, if the above hypothesis holds true, decreased $\mathrm{BM}$ production of B-lymphocytes, in the transition from $\mathrm{MBL}^{\text {lo }}$ to $\mathrm{MBL}^{\text {hi }}$ and CLL, would probably translate into a progressively narrower B-cell repertoire and progressively lower coverage of all required antigen specificities and, thereby, to defective (new) B-cell responses against specific pathogens, as recently reported for 
pneumococcus [14]. Further $I G H$ repertoire analyses of purified normal pre-GC B-cell subsets from both MBL and CLL subjects are required to fully confirm this hypothesis.

Although total PB PC numbers were only reduced in $\mathrm{MBL}^{\text {hi }}$ and no statistically significant differences were observed in total MBC counts among the groups here studied, an altered distribution of B-cell subsets expressing distinct Ig-subclasses was observed among both antigenexperienced B-cell populations in MBL and CLL (Fig. 2). Such altered distribution was progressively more marked from $\mathrm{MBL}^{\text {lo }}$ to $\mathrm{MBL}^{\text {hi }}$ and CLL-0. Thus, while in $\mathrm{MBL}^{\text {lo }}$ only slightly decreased $\operatorname{IgM}^{+}$PC counts were found in the PB $(P=0.05$; Supplementary Figure 2A), together with normal MBC and Ig levels (Fig. 2c,d; Supplementary Figure 4 and Supplementary Figure 5), MBL hi subjects showed reduced numbers of $\mathrm{PC}$ populations of all Ig-subclass (Fig. 2a,b), except IgG3 ${ }^{+}$PC (Supplementary Figure 3B), together with lower numbers of $\mathrm{IgG}^{+}$and $\mathrm{IgG}^{+} \mathrm{MBC}$ (Supplementary Figure 4B and 4F). In turn, CLL-0 patients showed decreased $\operatorname{IgM}^{+}, \operatorname{IgG} 2^{+}, \operatorname{IgG}^{+}$, and $\operatorname{IgA} 2^{+} \mathrm{PC}$ counts (Supplementary Figure 3 ) and low $\mathrm{IgG}^{+}, \mathrm{IgG}^{+}$, and IgA2 ${ }^{+}$MBC numbers (Supplementary Figure 4), which translates into overall decreased numbers of PCs and MBCs expressing those Ig-subclasses encoded downstream in the IGHC gene (Fig. 2b). Of note, no seasonal differences existed in recruitment among the four study groups, suggesting that differences in $\mathrm{PC}$ and $\mathrm{MBC}$ subset numbers were not influenced by seasonal changes.

Regarding plasma Ig titers, soluble IgM levels were significantly reduced in both $\mathrm{MBL}^{\text {hi }}(P=0.03)$ and CLL-0 $(P=0.008)$ (Fig. 2e); in addition, $\mathrm{MBL}^{\text {hi }}$ showed reduced IgG2 and IgG4 soluble levels (Supplementary Figure 5C-E) while CLL-0 patients displayed overall decreased plasma levels of all IgG-subclasses $(P \leq 0.02)$, particularly also of those encoded downstream in the IGHC gene (i.e., $\operatorname{IgG} 2$, IgG4, and $\operatorname{IgA} 2 ; P \leq 0.001 ;$ Fig. 2f). Thus, the overall reduction in soluble IgG titers was mostly at the expense of Ig-subclasses coded downstream in the third block IGHC gene, mimicking the altered PC and MBC profiles described above for the same patients (Supplementary Figure 5).

Altogether, these results suggest that $\operatorname{IgM}^{+} \mathrm{PC}$ responses are already hampered in $\mathrm{MBL}^{\text {lo }}$, while they are associated with different patterns of alteration of other normal residual antigen-experienced B-cells in MBL ${ }^{\text {hi }}$ and CLL-0. Thus, while in $\mathrm{MBL}^{\text {hi }}$ almost all $\mathrm{PC}$ populations were already reduced, and only few (decreased $\mathrm{IgG}^{+}$and $\mathrm{IgG}^{+}{ }^{+} \mathrm{MBC}$ ) alterations were observed in the distribution of the distinct MBC subpopulations analyzed, a lower number of PC subsets, together with a greater number of MBC subsets, were affected in CLL-0. Of note, MBC and PC expressing Ig-subclasses which are encoded downstream in the $I G H C$ gene (i.e., $\operatorname{IgG} 2^{+}, \mathrm{IgG}_{4}^{+}$, and $\operatorname{IgA} 2^{+}$) were the only antigen-experienced B-cell populations decreased in CLL (Fig. 2a, d).

These later findings point out the existence of a progressive deterioration of $\mathrm{B}$-cell responses driven by newly encountered Ags from $\mathrm{MBL}^{\text {lo }}$ to $\mathrm{MBL}^{\text {hi }}$ and CLL-0. This is likely due to an impaired pre-GC B-cell production, that would lead to a progressively reduced B-cell repertoire, with decreased production of new Ag-experienced B-cells from $\mathrm{MBL}^{\text {lo }}$ to $\mathrm{MBL}^{\text {hi }}$ and CLL-0. This immunodeficiency state might explain the previously reported reactivation in CLL of B-cell responses against common pathogens, particularly host-viruses such as cytomegalovirus (CMV) and Epstein Barr virus (EBV) [14]. The regeneration of PB PC numbers here reported between MBL ${ }^{\text {hi }}$ and CLL- 0 could be, thereby, due to such reactivation of antibody responses against common (dominant) antigens, including new antibody responses against CMV and EBV [14]; this is consistent with the apparent recovery of the number of PB PCs (and also MBCs) expressing Ig-subclasses, which are coded upstream in the $I G H C$ gene block (i.e., $\mathrm{IgG}^{+}, \mathrm{IgG}^{+}$, and $\operatorname{IgA} 1^{+}$) as found here for CLL-0 patients. These results would also support the higher frequency of infections driven by encapsulated bacteria in MBL and CLL patients, since $\operatorname{IgG} 2$ is the main actor in the humoral defense against polysaccharide antigens, and it was significantly reduced in both $\mathrm{MBL}^{\text {hi }}$ and CLL [15]. Further longitudinal long-term follow-up studies in larger series of newly diagnosed/ untreated MBL and CLL patients, including functional antigen-specific PC and MBC in vitro assays, are necessary to confirm this hypothesis.

Acknowledgements This work was supported by the RD06/0020/ 0035 and RD12/0036/0048 grants from Red Temática de Investigación Cooperativa en Cáncer (RTICC), Instituto de Salud Carlos III, Ministerio de Economía y Competitividad, (Madrid, Spain and FONDOS FEDER); CB16/12/00400 and CB16/12/00233 grants, CIBERONC, Instituto de Salud Carlos III, Ministerio de Economía y Competitividad, (Madrid, Spain and FONDOS FEDER); the FIS PI06/0824FEDER, PS09/02430-FEDER, PI12/00905-FEDER, DTS15/00119FEDER, and PI17/00399-FEDER grants, from the Fondo de Investigación Sanitaria of Instituto de Salud Carlos III; the GRS206/A/08 grant (Ayuda al Grupo GR37 de Excelencia, SAN/1778/2009) from the Gerencia Regional de Salud (Consejería de Educación and Consejería de Sanidad of Castilla y León, Valladolid, Spain). MLG is supported by grant PTA2014-09963-I from the Instituto de Salud Carlos III and AR-C is supported by grant CB16/12/00400, Instituto de Salud Carlos III, Ministerio de Economía y Competitividad. The authors would like to thank the Spanish National DNA Bank (Banco Nacional de ADN Carlos III, University of Salamanca) and all the members of The Primary Health Care Group of Salamanca for the Study of $M B L$, here listed (alphabetical order): Alonso Martín, María Monserrat (C.S. Fuentes de Oñoro); Asensio Oliva, María Carmen (C. S. Santa Marta de Tormes), Bárez Hernández, Pilar (C.S. Garrido Sur); Cabo Sastre, Luis (C.S. Garrido Sur); Carreño Luengo, María Teresa (C.S. Garrido Sur); Casado Romo, José María (C.S. Alba de Tormes); Cubino Luis, Rocio (C.S. Universidad-Centro); De Vega Parra, José (C.S. Peñaranda); Franco Esteban, Eloy (C.S. Pizarrales-Vidal); García García, María Concepción (C.S. Guijuelo); García Rodríguez, 
Bernardo Lucio (C.S. Pizarrales-Vidal); Garzón Martín, Agustín (C.S. Universidad-Centro); Goenaga Andrés, Rosario (C.S. Ledesma); Gómez Cabrera, Rosalia (C.S. Miguel Armijo); Gómez Sánchez, Francisco (C.S. Periurbana Norte); González Moreno, Josefa (C.S. Béjar); González Vicente, Ángel Carlos (C.S. Linares); Guarido Mateos, José Manuel (C.S. Vitigudino); Hernández Sánchez, María Jesús (C.S. Vitigudino); Herraez Martín, Ricardo (C.S. La Alberca); Herrero Sánchez, Amparo (C.S. Fuentes de Oñoro); Jiménez Ruano, María Josefa (C.S. Garrido Norte); Jimeno Cascón, Teresa Basa (C.S. Periurbana Sur); Macías Kuhn, Francisco (C.S. Ledesma); Mateos Rubio, Pablo (C.S. Ledesma); Márquez Velasco, María Salud (C.S. Sancti Spiritus); Merino Palazuelo, Miguel (C.S. Garrido Sur); Miguel Lozano, Rubén (C.S. Garrido Norte); Montero Luengo, Juan (C.S. San Juan); Muriel Díaz, María Paz (C.S. Miguel Armijo); Pablos Regueiro, Araceli (C.S. Lumbrales); Pascual Martín, J. Antonio (C.S. Fuentes de Oñoro); Pastor Alcalá, Luis (C.S. Vitigudino); Pedraza García, Jesús (C.S. Lumbrales); Pérez Díaz, Manuel (C.S. Pizarrales-Vidal); Pérez García, Manuel (C.S. Alba de Tormes); Prieto Gutiérrez, María Teresa (C.S. Peñaranda); Ramos Arranz, Manuel (C.S. Ledesma); Ramos Mongue, Aurora Esther (C.S. Béjar); Rodríguez Medina, Ana María (C.S. Alba de Tormes); Rodríguez Vegas, Margarita (C.S. Periurbana Sur); Romo Cortina, Javier (C.S. Elena Ginel Díez); Elena Roselló, Carmen (C.S. Villoria); Sánchez Alonso, Begoña (C.S. PizarralesVidal); Sánchez Bazo, Begoña (C.S. Periurbana Norte), Sánchez White, Nicolás (C.S. Béjar); Sandín Pérez, Rafael (C.S. San José); Sanz Santa-Cruz; Fernando (C.S. Capuchinos); Soto Jiménez, Francisco (C.S. Linares); Velasco Marcos, María Auxiliadora (C.S. Elena Ginel Díez); Vicente López, Horacio Marcos (C.S. Aldeadávila de la Ribera); Vicente Santos, M. Sebastián (C.S. Aldeadávila de la Ribera).

\section{Compliance with ethical standards}

Conflict of interest The authors declare that they have no conflict of interest.

Open Access This article is licensed under a Creative Commons Attribution 4.0 International License, which permits use, sharing, adaptation, distribution and reproduction in any medium or format, as long as you give appropriate credit to the original author(s) and the source, provide a link to the Creative Commons license, and indicate if changes were made. The images or other third party material in this article are included in the article's Creative Commons license, unless indicated otherwise in a credit line to the material. If material is not included in the article's Creative Commons license and your intended use is not permitted by statutory regulation or exceeds the permitted use, you will need to obtain permission directly from the copyright holder. To view a copy of this license, visit http://creativecommons. org/licenses/by/4.0/.

\section{References}

1. Rai KR, Jain P. Chronic lymphocytic leukemia (CLL)-Then and now. Am J Hematol. 2016;91:330-40.
2. Landgren O, Albitar M, Ma W, Abbasi F, Hayes RB, Ghia P, et al. B-cell clones as early markers for chronic lymphocytic leukemia. N Engl J Med. 2009;360:659-67.

3. Swerdlow SH, Campo E, Harris NL, Jaffe ES, Pileri SA, Stein H, et al. WHO classification of tumours of haematopoietic and lymphoid tissues. 4th ed. Lyon, France: IARC; 2017.

4. Nieto WG, Almeida J, Romero A, Teodosio C, Lopez A, Henriques $\mathrm{AF}$, et al. Increased frequency (12\%) of circulating chronic lymphocytic leukemia-like B-cell clones in healthy subjects using a highly sensitive multicolor flow cytometry approach. Blood. 2009;114:33-7.

5. Almeida J, Nieto WG, Teodosio C, Pedreira CE, Lopez A, Fernandez-Navarro P, et al. CLL-like B-lymphocytes are systematically present at very low numbers in peripheral blood of healthy adults. Leukemia. 2011;25:718-22.

6. Shanafelt TD, Ghia P, Lanasa MC, Landgren O, Rawstron AC. Monoclonal B-cell lymphocytosis (MBL): biology, natural history and clinical management. Leukemia. 2010;24:512-20.

7. Fazi C, Scarfò L, Pecciarini L, Cottini F, Dagklis A, Janus A, et al. General population low-count CLL-like MBL persists over time without clinical progression, although carrying the same cytogenetic abnormalities of CLL. Blood. 2011;118: 6618-25.

8. Criado I, Rodriguez-Caballero A, Gutierrez ML, Pedreira CE, Alcoceba M, Nieto W, et al. Low-count monoclonal B-cell lymphocytosis persists after 7 years of follow-up and is associated with a poorer outcome. Haematologica. 2018. https://doi.org/10. 3324/haematol.2017.183954.

9. Moreira J, Rabe KG, Cerhan JR, Kay NE, Wilson JW, Call TG, et al. Infectious complications among individuals with clinical monoclonal B-cell lymphocytosis (MBL): a cohort study of newly diagnosed cases compared to controls. Leukemia. 2013;27:136-41.

10. Forconi F, Moss P. Perturbation of the normal immune system in patients with CLL. Blood. 2015;126:573-81.

11. Hauswirth AW, Almeida J, Nieto WG, Teodosio C, RodriguezCaballero A, Romero A, et al. Monoclonal B-cell lymphocytosis (MBL) with normal lymphocyte counts is associated with decreased numbers of normal circulating B-cell subsets. Am J Hematol. 2012;87:721-4.

12. Blanco E, Perez-Andres M, Arriba-Mendez S, ContrerasSanfeliciano T, Criado I, Pelak O, et al. Age-associated distribution of normal B-cell and plasma cell subsets in peripheral blood. J Allergy Clin Immunol. 2018. https://doi.org/10.1016/j.jaci.2018. 02.017 .

13. Fecteau J-F, Kipps TJ. Structure and function of the hematopoietic cancer niche: focus on chronic lymphocytic leukemia. Front Biosci (Schol Ed). 2012;4:61-73.

14. Criado I, Munoz-Criado S, Rodriguez-Caballero A, Nieto WG, Romero A, Fernandez-Navarro P, et al. Host virus and pneumococcus-specific immune responses in high-count monoclonal B-cell lymphocytosis and chronic lymphocytic leukemia: implications for disease progression. Haematologica. 2017; 102:1238-46.

15. Chudwin DS, Artrip SG, Schiffman G. Immunoglobulin G class and subclass antibodies to pneumococcal capsular polysaccharides. Clin Immunol Immunopathol. 1987;44:114-21. 